JOTE Volume 2 Nomor 1 Tahun 2020 Halaman 247-255 JOURNAL ON TEACHER EDUCATION Research \& Learning in Faculty of Education

\title{
Penerapan Model Pembelajaran Probing Prompting untuk Meningkatkan Kemampuan Pemecahan Masalah Matematis
}

\author{
Fitri Lestari ${ }^{1}$ Rusdial Marta, M.Pd ${ }^{2}$ Vigi Indah, $\mathbf{M} . \mathbf{P d}^{3}$ \\ SI PG-PAUD, Fakultas IImu Pendidikan, Universitas Pahlawan Tuanku Tambusai \\ lestarifit8@gmail.com
}

\begin{abstract}
Abstrak
Penelitian ini bertujuan untuk mendeskripsikan pendidikan anak usia dini pada keluarga muda di Desa Sumber Makmur Kecamatan Tapung. Penelitian ini termasuk jenis penelitian kualitatif deskriptif. Keluarga muda yang memiliki anak usia dini. Data dikumpulkan melalui pengamatan dan wawancara. Teknik analisis data yang digunakan mengacu pada konsep Milles dan Huberman. Hasil penelitian menunjukkan bahwa: 1) Pola asuh yang ada pada keluarga muda di Desa Sumber Makmur terdiri dari 2 jenis pola asuh, yaitu pola asuh permisif dan otoriter; 2) Fasilitas yang diberikan sudah memberikan fasilitas bagi pendidikan dan pengembangan diri anak usia dini mereka; 3) Pemantauan terhadap perkembangan (fisik-motorik, kognitif, dan afektif) anak melalui hasil-hasil dari pembelajaran anak, baik pembelajaran yang anak peroleh di sekolah ataupun hasil dari pembelajaran yang anak peroleh saat belajar bersama orangtua di rumah.
\end{abstract}

Kata kunci: Pendidikan, Keluarga muda, Anak usia dini

\begin{abstract}
This study aims to describe early childhood education in young families in Sumber Makmur Village, Tapung District. This research is a descriptive qualitative research. Young families with early childhood. Data were collected through observation and interviews. The data analysis technique used refers to the concept of Milles and Huberman. The results showed that: 1) The existing parenting styles in young families in Sumber Makmur Village consisted of 2 types of parenting, namely permissive and authoritarian parenting; 2) The facilities provided have provided facilities for their early childhood education and selfdevelopment; 3) Monitoring the development (physical-motor, cognitive, and affective) of children through the results of children's learning, both learning that children get at school or the results of learning that children get when studying with their parents at home.
\end{abstract}

Keywords: Education, Young family, Early childhood 


\section{PENDAHULUAN}

Matematika merupakan ilmu yang memegang peranan penting dalam dunia pendidikan. Belajar matematika dipandang sebagai suatu cara melatih kemampuan komunikasi matematis siswa untuk mengkomunikasikan materi dengan baik, logis, dan teratur (Marta Rusdial, 2017). Matematika merupakan ilmu dasar yang memiliki peranan penting dalam segala aspek kehidupan. Matematika termasuk salah satu mata pelajaran yang harus diajarkan dalam dunia pendidikan, mulai dari undang-undang nomor 20 tahun 2003 tentang system pendidikan nasional pendidikan nasional tepatnya pada bab X pasal 37 ayat (1) yang menjelaskan bahwa kurikulum pendidikan dasar dan menengah wajib memuat Pendidikan Agama, Pendidikan Kewarganegaraan, Bahasa, Matematika, IImu Pengetahuan Alam, IImu Pengetahuan Sosial, Seni dan Budaya, Pendidikan Jasmani dan Olahraga, Keterampilan/Kejuruan, dan Muatan Lokal. Matematika sangat penting bagi kehidupan manusia. Hal ini dapat kita lihat, bahwa kegiatan sehari-hari manusia tidak akan terlepas dari perhitungan yang dasar dari pelajaran matematika, terutama dalam bertransaksi maupun dalam mengukur atau membangun suatu bangunan.

Hudojo (2015), menyatakan bahwa,"Matematika merupakan ide-ide abstrak yang diberi simbol-simbol yang tersusun secara hirarkis dan penalarannya deduktif sehingga belajar matematika itu merupakan kegiatan mental yang tinggi". Hal ini menunjukkan bahwa konsep - konsep dalam matematika tersusun mulai dari konsep yang paling sederhana sampai pada konsep paling kompleks. Menurut Cockroft (2009), menyatakan bahwa matematika perlu diajarkan kepada siswa karena (1) selalu digunakan dalam segi kehidupan; (2) semua bidang studi memerlukan keterampilan matematika yang sesuai; (3) merupakan sarana komunikasi yang kuat, singkat, dan jelas; (4) dapat digunakan untuk menyajikan informasi dalam berbagai cara; (5) meningkatkan kemampuan berfikir logis, ketelitian, dan kesadaran keruangan; (6) memberikan kepuasan terhadap usaha memecahkan masalah yang menantang". Lebih lanjut lagi, menurut Lerner (2009) bahwa "kurikulum matematika hendaknya mencakup tiga elemen, (1) konsep, (2) keterampilan, dan (3) pemecahan masalah. Salah satu kemampuan yang harus dikembangkan adalah kemampuan memecahkan masalah. Pembelajaran yang berpusat pada guru juga terjadi dalam pembelajaran Matematika pada siswa kelas IV SDN 002 Kuok. Hal ini diketahui dari wawancara yang dilakukan pada kelas empat di SDN 002 Kuok pada hari Senen, 09 Maret 2020. Informasi sebagai berikut: 1) Guru cenderung menggunakan metode ceramah, 2) Siswa kurang mampu memahami materi yang disampaikan oleh guru, 3) Siswa dalam mengerjakan soal tidak menggunakan langkah-langkah penyelesaian, 4) Rendahnya kemampuan siswa dalam pemecahan masalah sehingga hasil belajar kurang maksimal, 5) Model pembelajaran kurang bervariasi, 6) Siswa sering rebut sendiri maupun berbicara dengan temannya saat guru menjelaskan materi, 7) Siswa hanya pasif mendengarkan penjelasan dari guru.Berdasarkan hasil wawancara tersebut, dapat diketahui adanya kesenjangan antara apa yang seharusnya dilakukan dan kenyataan dalam penerapan pembelajaran. Berdasarkan permasalahan tersebut, perlu adanya inovasi dari guru dalam menerapkan model pembelajaran matematika di SDN 002 Kuok. Model pembelajaran yang diterapkan dalam 
pembelajaran hendaknya dirancang sesuai dengan karakteristik materi pembelajaran, kondisi siswa dan lingkungan sekolah.

Model pembelajaran yang diterapkan yaitu model pembelajaran Probing Prompting akan mampu menjadikan siswa lebih berpikir kritis karena guru memberikan penjelasan dan pertanyaan untuk menggali wawasan terhadap materi yang diberikan. Dalam penerapan pendekatan pembelajaran Probing Prompting siswa dituntut untuk menjadi subjek belajar dalam memecahkan masalah matematika sehingga kemampuan pemecahan masalah matematika siswa dapat meningkat dan kecerdasannya pun dapat berkembang.

Materi ajar dalam penelitian ini difokuskan pada materi Faktor Persekutuan Terbesar (FPB) dan Kelipatan Persekutuan Terkecil (KPK) menjadi salah satu materi pokok bahasan yang harus dipelajari pada kelas IV semester I. Pada materi ini peserta didik mengalami kesulitan dalam menyelesaikan soal yang berkaitan dengan FPB dan KPK. Banyak peserta didik yang tidak mampu memahami soal dalam melakukan perhitungan yang berhubungan dengan kegiatan menjumlah, mengurangkan, mengali, dan bahkan tidak mampu membagi. Oleh karena itu, perlu dilakukan pengujian terhadap model pembelajaran Probing Prompting.

Berdasarkan latar belakang masalah tersebut, peneliti ingin melakukan penelitian tindakan kelas dengan judul " Penerapan Model Pembelajaran Probing Prompting untuk Meningkat Kemampuan Pemecahan Masalah Matematis”.

\section{METODE}

Berdasarkan rumusan masalah, peneliti menggunakan penelitian Penelitian Tindakan Kelas (PTK), karena peneliti akan melakukan penelitian berbentuk refleksi. Hakikat PTK menurut Sukardi (2013), adalah, "suatu bentuk penelitian refleksi dari (self reflective) yang dilakukan oleh para partisipan dalam situasi sosial untuk memperbaiki rasionalis atau kebenaran. Kusumah (2008), memandang, "Hakikat PTK adalah sebagai bentuk penelitian efektif yang dilakukan oleh guru sendiri dan hasilnya dapat dimanfaatkan sebagai alat untuk mengembangkan keahlian mengajar.

Prosedur penelitian tindakan kelas ini berbentuk siklus, setiap siklus terdapat 2 pertemuan yang terdiri dari empat tahap, yaitu perencanaan (planning), tindakan (acting), Obsevasi (observer), dan refleksi (reflection). gambar 3.

Prosedur penelitian yang digunakan dalam penelitian ini dapat dilihat pada 


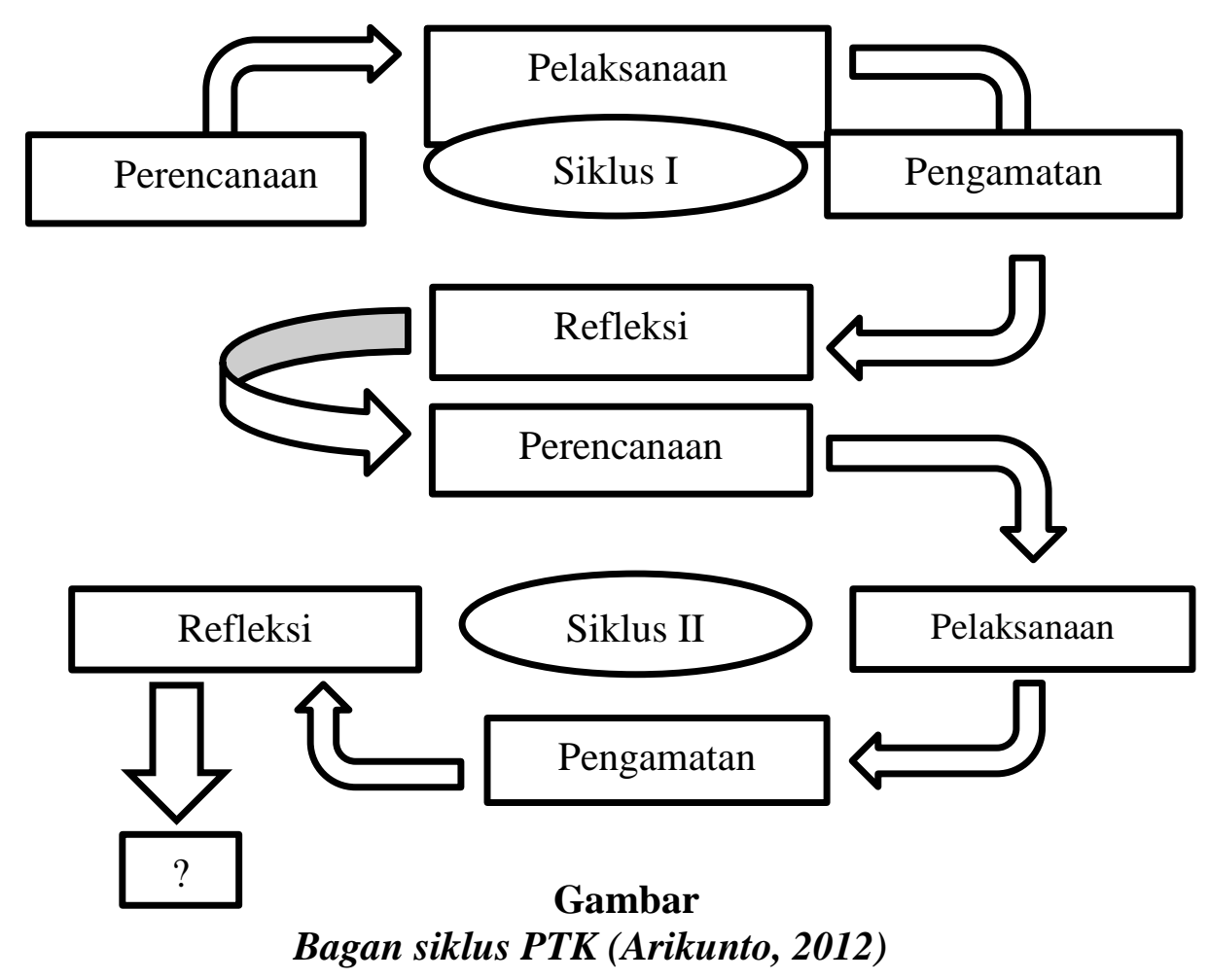

\section{PEMBAHASAN}

Kegiatan Pra siklus ini bertujuan untuk mengetahui bagaimana melatih kemampuan pemecahan masalah pada siswa kelas IV sebelum diberikan berupa tindakan. Pra siklus dalam penelitian ini dilaksanakan pada tanggal 22 September 2020. Peneliti melakukan kegiatan pengamatan terhadap siswa ketika kegiatan belajar mengajar berlangsung dan pengamatan ini dilaksanakan ketika peneliti melakukan wawancara dan observasi awal pada tanggal 09 Maret 2020. Peneliti memberikan soal pada tanggal 22 September 2020 yang dilaksanakan sebelum memberikan tindakan yang mana bertujuan agar megetahui peningkatan kemampuan pemecahan masalah pada siswa kelas IV.

Penelitian ini dilaksanakan dalam dua siklus, peneliti berkolaborasi dengan guru kelas dan teman sejawat. Peneliti berperan sebagai guru yang mengajar, guru kelas IV SD Negeri 002 Kuok berperan sebagai observer aktivitas guru dan teman sejawat berperan sebagai aktivitas siswa. Berikut pemaparan penelitian tindakan kelas terhadap pemecahan masalah matematika siswa kelas IV SD Negeri 002 Kuok. Sebelum melaksanakan penelitian tindakan kelas, terlebih dahulu peneliti menganalisi data awal hasil belajar (data prasiklus) yang diperoleh dari hasil soal evaluasi pemecahan masalah materi KPK dan FPB di kelas IV SDN 002 Kuok

Data tersebut diperoleh saat peneliti melakukan observasi untuk melihat proses pembelajaran yang berlangsung dengan guru kelas terkait kemampuan siswa dalam pemecahan masalah matematika. Peneliti mengamati proses pembelajaran matematika yang berlangsung di kelas IV SD Negeri 002 Kuok pada tanggal 28 September 2020.

Berdasarkan data nilai tes pratindakan dapat diketahui, nilai rata-rata siswa pada tes awal adalah sebesar 53,27 dan presentase ketuntasan belajar $9 \%$. Sehingga hasli dari pre test sangat jauh dengan ketuntasan kelas yang diinginkan oleh peneliti yaitu $80 \%$. Dengan hasil pre test itu, peneliti memutuskan 
untuk mengadakan penelitian pada materi KPK dan FPB dengan menggunakan model pembelajaran Probing Prompting untuk meningkatkan kemampuan pemecahan masalah matematika. Pada materi ini peneliti menetapkan KKM (Kriteria Ketuntasan Minimal 70 dengan tujuan untuk mengetahui perbedaan sebelum diadakan penerapan pembelajaran menggunakan model pembelajaran Probing Prompting dan sesudah diadakan penerapan menggunakan model pembelajaran ini.

Berdasarkan hasil penelitian dilaksanakan perbaikan pada siklus berikutnya. Kekurangan pada siklus I dapat diperbaiki pada siklus II sehingga diperoleh peningkatan aktivitas guru, aktivitas belajar siswa dan hasil kemampuan pemecahan masalah yang maksimal. Yang tuntas hanya 4 siswa dengan persentase nilai $36 \%$ dan yang tidak tuntas lebih banyak dengan jumlah siswa 7 orang persentase nilai 64\%. Rendahnya nilai siswa disebabkan siswa masih belum terbiasa dengan penerapan model pembelajaran Probing Prompting dalam pembelajaran matematika, pada saat mengerjakan soal evaluasi masih ada yang menyontek dan masih bingung terhadap soalnya dan hasil jawaban mereka masih banyak yang kurang sempurna dalam memecahkan masalah sehingga nilai mereka masih yang kurang KKM.

Perbandingan Hasil Kemampuan Pemecahan Masalah Matematika Siswa Kelas IV Abu Bakar Berdasarkan Data Pratindakan Dengan Hail Evaluasi Siklus I dan Siklus II

\begin{tabular}{|c|c|c|c|c|c|}
\hline \multirow[t]{2}{*}{$\mathrm{NO}$} & \multirow[t]{2}{*}{$\begin{array}{l}\text { Persentase } \\
\quad \text { Nilai }\end{array}$} & \multirow[t]{2}{*}{ Kualifikasi } & \multicolumn{3}{|c|}{$\begin{array}{l}\text { Hasil Kemampuan Pemecahan Masalah } \\
\text { Matematika Siswa }\end{array}$} \\
\hline & & & Pratindakan & Siklus I & Siklus II \\
\hline 1 & $90-100 \%$ & Sangat Baik & $\begin{array}{c}0 \\
(0 \%)\end{array}$ & $\begin{array}{c}0 \\
(0 \%)\end{array}$ & $\begin{array}{c}2 \\
(18 \%)\end{array}$ \\
\hline 2 & $80-89 \%$ & Baik & $\begin{array}{c}0 \\
0 \\
(0 \%)\end{array}$ & $\begin{array}{c}2 \\
(18 \%)\end{array}$ & $\begin{array}{c}4 \\
(36 \%)\end{array}$ \\
\hline 3 & $70-79 \%$ & Cukup Baik & $\begin{array}{c}1 \\
(9 \%)\end{array}$ & $\begin{array}{c}2 \\
(18 \%)\end{array}$ & $\begin{array}{c}3 \\
(27 \%)\end{array}$ \\
\hline 4 & $60-69 \%$ & Kurang Baik & $\begin{array}{c}4 \\
(36 \%)\end{array}$ & $\begin{array}{c}1 \\
(9 \%)\end{array}$ & $\begin{array}{c}1 \\
(9 \%)\end{array}$ \\
\hline 5 & $<60 \%$ & $\begin{array}{l}\text { Sangat } \\
\text { Kurang }\end{array}$ & $\begin{array}{c}6 \\
(54 \%)\end{array}$ & $\begin{array}{c}6 \\
(54 \%)\end{array}$ & $\begin{array}{c}1 \\
(9 \%)\end{array}$ \\
\hline \multicolumn{3}{|c|}{ JUMLAH } & $\begin{array}{c}11 \\
(100 \%)\end{array}$ & $\begin{array}{c}11 \\
(100 \%)\end{array}$ & $\begin{array}{c}11 \\
(100 \%)\end{array}$ \\
\hline
\end{tabular}

Berdasarkan tabel 4.4 di atas, diketahui bahwa hasil kemampuan pemecahan masalah matematika siswa kelas IV Abu Bakar dengan menggunakan model pembelajaran Probing Prompting meningkat. Pada siklus I dari 11 orang siswa yang mencapai kualifikasi sangat baik tidak ada dengan persentase $0 \%$, kualifikasi baik ada 2 orang siswa dengan persentase $18 \%$, kulifikasi cukup baik ada 2 orang siswa dengan persentase $18 \%$ dan kurang baik 1 orang siswa dengan persentase $9 \%$ dan kualifikasi sangat kurang 6 orang siswa dengan persentase $54 \%$.

Hasil kemampuan pemecahan masalah yang diperoleh pada siklus II juga mengalami peningkatan, yaitu dari 11 orang siswa yang mencapai kualifikasi sangat baik ada 2 orang siswa dengan persentase nilai $18 \%$, karena sudah mulai memahami konsep materi yang diberikan. Kualifikasi baik ada 4 orang siswa dengan persentase nilai $36 \%$, dan kualifikasi cukup baik ada 3 orang siswa 
dengan persentase nilai $27 \%$, lalu kualifikasi kurang ada 1 orang siswa dengan persentase $9 \%$ terakhir kualifikasi sangat kurang ada 1 orang siswa dengan persentase nilai $9 \%$.

Berdasarkan penelitian yang telah dilaksanakan, pada siklus I hasil kemampuan pemecahan masalah matematika siswa kelas IV Abu Bakar menunjukkan peningkatan dari tindakan sebelumnya. Peningkatan hasil kemampuanpemecahan masalah matematika siswa pada tiap siklus dapat di lihat pada grafik berikut ini.

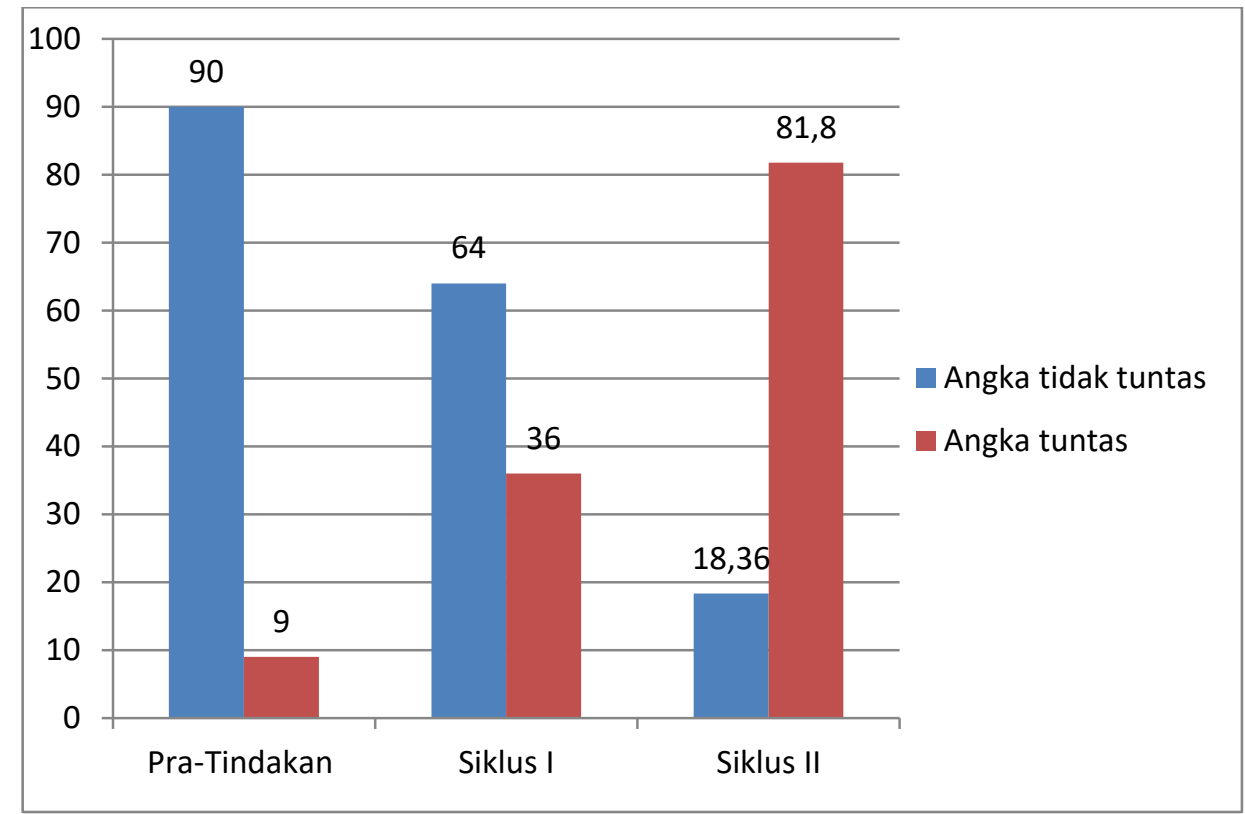

\section{Grafik Peningkatan Hasil Kemampuan Pemecahan Masalah Matematika Siswa Kelas IV Abu Bakar Berdasarkan Data Pratindakan Dengan Hasil Evaluasi Siklus I dan II}

\section{KESIMPULAN}

Berdasarkan hasil penelitian yang telah dijabarkan pada bab IV, diketahui bahwa hasil kemampuan pemecahan masalah matematika siswa kelas IV Abu Bakar pada Pra-tindakan siswa yang mencapai kualifikasi baik sebanyak 0 orang siswa dengan presentase $0 \%$ kualifikasi cukup baik sebanyak 1 orang siswa dengan persentase $9 \%$ kualifikasi kurang baik sebanyak 4 orang dengan persentase $36,3 \%$ dan kualifikasi sangat kurang sebanyak 6 orang dengan persentase $54,5 \%$. Pada siklus I dari 11orang siswa yang mencapai kualifikasi sangat baik ada 0 orang siswa dengan persentase $00 \%$ kualifikasi baik ada 2 orang siswa dengan persentase 18\% kualifikasi cukup baik ada 2 orang siswa dengan persentase $18 \%$ dan kualifikasi cukup baik ada 2 orang siswa dengan persentase $18 \%$ kualifikasi kurang baik ada 1 orang siswa dengan persentase $9 \%$ dan kualifikasi sangat kurang asa 6 orang siswa dengan persentase 54,5. Sedangkan pada siklus II siswa yang mencapai kualifikasi sangat baik sebanyak 2 orang siswa dengan persentase $18 \%$ kualifikasi baik sebanyak 4 orang siswa dengan persentase $36,3 \%$ dan kualifikasi cukup baik sebanyak 3 orang siswa dengan persentase $27,2 \%$. 
Rata-rata hasil kemampuan pemecahan masalah matematika pada pratindakan mencapai 53,27 dengan kualifikasi kurang, pada siklus I meningkat menjadi 57,36 dengan kualifikasi cukup dan pada siklus II meningkat menjadi 78,36 dengan kualifikasi baik. Hal ini membuktikan bahwa dengan menggunakan model pembelajaran Probing Prompting dapat meningkat kemampuan pemecahan masalah matematika siswa kelas IV SDN 002 Kuok.

\section{DAFTAR PUSTAKA}

Ambarwati. (2013). "Pengaruh Strategi Pembelajaran dan Penalaran Formal Terhadap Hasil Belajar Matematika Siswa Sekolah Menengah Atas (Swasta) Al Ulum Medan.” Jurnal Tabularasa PPS UNIMED.

Arends.2018. Dasar-dasar Penelitian Pendidikan Bidang Non-Eksakta Lainnya. Bandung: P.T. Tarsito

Arikunto, 50 Tipe Pembelajaran Kooperatif, ( Medan, Media Persada, 2014).

Cockraft.2009. Pemecahan Masalah Matematika. UPIPRESS.Bandung

Dahar.2017. Model-Model Pengajaran dan Pembelajaran, (Yogyakarta,Pustaka Pelajar, 2017).

Daniel Muijss.2008. Teori Belajar dan Pembelajaran, Yogyakarta:Ar-Ruzz Media.

Denim.2011.Matematika Sebagai Pemecahan Masalah, bandung: Setia Budi.

Erman.2008. Penerapan Pembelajaran Kontekstual Berbasis Potensi Pesisir sebagai Upaya Peningkatan Kemampuan Pemecahan Masalah Matematik, Komunikasi Matematik, dan Keterampilan Sosial Siswa SMP. Disertasi pada SPS UPI.: Tidak Diterbitkan.

Evans.2014. Pemecahan Masalah Matematika. UPIPRESS.Bandung.

Fatimah, Trind Pengajaran dan Pembelajaran Matematika Utusan Publicatoin \& Distributor SDN BHN, Kuala Lumpur:Print-Ad Sdn-Bhn, 2009.

Huda.2014. Dasar-dasar Penelitian Pendidikan Bidang Non-Eksakta Lainnya. Bandung: P.T. Tarsito.

Hudojo.2015. Pengaruh Model Pembelajaran Think Pair Share (TPS) terhadap Kemampuan Memahami Unsur Intrinsik Cerpen pada Siswa Kelas X SMA Negeri 8 Padang sidimpuan. Vol.1 No 1. Desember 2016.

Marta. R ( 2017). “Peningkatan Hasil Belajar Matematika Dengan Pendekatan Problem Solving Siswa Sekolah Dasar" Universitas Pahlawan Tunaku Tambusai No. 23 Bangkinang. Vol 1(1).

Marta. R (2017). “ Peningkatan Hasil Belajar Matematika Siswa Kelas IV SDN 008 Langgini Melalui Penerapan Pembelajaran Kooperatif Dengan Teknik Kancing Gemerincing" Vol. 7, (1). 
Istarani. 2011. Model Pembelajaran Inovatif Kurikulum 2013. Ar-Ruzz Media. Yogyakarta.

John Dewey. 2009. 58 Model Pembelajaran Inovatif. Medan. Media Persada

Joice, Weil. 2013. Model-Model Pengajaran dan Pembelajaran Isu-Isu Metodis dan Paradigmatis. Pustaka Pelajar. Yogyakarta

Kosasih. 2014. Pengaruh Penggunaan Model Pembelajaran Student Facilitator and Explaining Terhadap Pemahaman Matematik Peserta Didik. Jurnal Penelitian Pendidikan dan Pengajaran Matematika. Vol. 2 No. 1 Maret 2016.

Kusumah. 2015. Pengaruh Penggunaan Metode Student Facilitator and Explaining terhadap Kemampuan Pemecahan Masalah Matematik Siswa SMK di Kota Tasikmalaya. Jurnal Penelitian Pendidikan dan Pengajaran Matematika. Vol. 1 No. 1 September 2015.

Lerner. 2009. Student's Character Building Through Guided Discovery Learning With Probing Prompting Strategi. International Journal. Purwokerto.

Mawaddah, Annisa. 2015. Pengaruh Penerapan Pendekatan Keterampilan Proses terhadp Kemampuan Pemecahan Masalah Matematis Siswa SMP. Prosiding Seminar Nasional Pendidikan Matematika STKIP Siliwangi.

Moleory. 2015. Efektivitas Penerapan Model Pembelajaran Student Facilitator and Explaining Menggunakan Concept Map terhadap Peningkatan Pemahaman Konsep. Jurnal Pendidikan Fisika. Vol. 4 No. 2 September 2016. 71-74.

Offirston. 2014. Analisis Korelasi Motivasi Berprestasi terhadap Kemampuan Pemecahan Masalah Matematika Siswa SMPN 3 Luragung Jabar. Jurnal Pendidikan Matematika. Volume 2.

Polya. 2001. Kurikulum Dan Pembelajaran. Bumi Aksara. Jakarta

Saad \& Ghani. 2008. Masalah Matematika di sekolah negeri. Jakarta.

Sardiman. 2010. Korelasi Pengetahuan Alat Praktikum Fisika dengan

Kemampuan Psikomotorik Siswa di SMA Negeri q Bengkulu. Jurnal Exacta. Vol. IX No.1. Juni 2011.

Soekamto. 2014. Dasar-dasar Penelitian Pendidikan Bidang Non-Eksakta Lainnya. Bandung: P.T. Tarsito.

Suherman. 2014. 68 Model Pembelajaran Inovatif Dalam Kurikulum 2013. Yogyakarta. Ar- Ruzz Media.

Sukardi. 2013. Pengaruh Pendekatan Open Ended terhadap Pemecahan Masalah Matematis Siswa Kelas X SMA Negeri 1 Halongonan. Jurnal Pendidikan MIPA STKIP “Tapanuli Selatan” Padangsidimpuan. Vol 001/ Nomor 6c. Hal 451-567. 
Susilawati. 2008. Model Pembelajaran Terpadu dalam Teori dan Praktek.

Jakarta. Prestasi Pustaka

Suprijono.2009. Pengembangan Pembelajaran Matematika SD. Dirjen

Pendidikan Tinggi Depdiknas. Jakarta.

Suyatno. 2014. Mengapa Harus Belajar Matematika?. Perdana Publishing. Medan.

Usman. 2003. Manajemen Penelitian. RinekaCipta. Jakarta.

Wardhani. 2007. The Implentation of The Polya Method in Solving Euclidean Geometry Problems.International Education Studies.

Wilson. 2013. The Development of Learning Materials of Online ProbingPrompting Method at IAIN Antasari in Indonesia. Al-Ta'Lim Jurnal. 24(1), HSBN. 